\title{
PENGARUH PEMBERIAN REWARD TERHADAP KEPUASAAN PELANGGAN PADA PT. ASABRI (PERSERO) KANTOR CABANG PEMBANTU LAMPUNG DI BANDAR LAMPUNG
}

\author{
Sodirin $^{(1)}$, Randi Pratama ${ }^{(2)}$ \\ Fakultas Ekonomi Universitas Sang Bumi Ruwa Jurai \\ sodirin@fe.saburai.ac.id,pratamarandi10@gmail.com
}

\begin{abstract}
Abstrak. Kualitas pelayanan terhadap kepuasan pelanggan dan kepuasan pelanggan yang diharapkan belum sepenuhnya dapat tercapai karena faktor permasalahan atau hambatan yang timbul dari karyawan. Adapun rumusan masalah dalam penelitian ini adalah apakah ada pengaruh pemberian reward terhadap kepuasaan pelanggan Pada PT. Asabri (Persero) Kantor Cabang pembantu Lampung, sedangkan yang menjadi tujuan dalam penelitian ini adalah untuk mengetahui pengaruh pemberian reward terhadap kepuasaan pelanggan dan hipotesis dalam penelitian ini adalah ada pengaruh pemberian reward terhadap kepuasaan pelanggan. Metode Penelitian yang digunakan adalah metode analisi kualitatif dan analisis kuantitatif. Berdasarkan hasil penelitian dari 25 responden tentang pengaruh pemberian reward terhadap peningkatan kepuasaan pelanggan PT. Asabri (Persero) KCP Lampung diperoleh koefisien regresi sebesar 34,610 dan konstanta sebesar 0.631, maka dapat digambarkan bentuk pengaruh variabel pemberian reward terhadap kepuasaan pelanggan dalam bentuk persamaan regersi $\mathrm{Y}=34,610+0.631 \mathrm{X}$ ini berarti bahwa jika pemberian reward meningkat sebesar 1 poin maka kepuasaan pelanggan akan meningkat sebesar 0.631 poin pada konstanta 34,610 . Sehingga dengan kata lain bahwa semakin baik pemberian reward maka kepuasaan pelanggan akan semakin tinggi.
\end{abstract}

Kata kunci: Kepuasan, Kualitas, Pelayanan, Reward.

\section{PENDAHULUAN}

Era globalisasi seperti saat ini perusahaan dituntut untuk memiliki efektifitas dan efisiensi yang tinggi, hal itu dapat menjadi keunggulan untuk bertahanan di tengah-tengah kondisi persaingan yang saat ini semakin pesat. Di dalam dunia bisnis, perusahaan yang dapat menghasilkan barang dan jasa berkualitaslah yang dapat masuk dan bersaing di pasar global. Karena tekanan itulah maka dalam pembentukan sebuah perusahaan yang berdaya saing tinggi terdapat beberapa faktor yang harus dipenuhi perusahaan agar dapat mengimbangi perubahan-perubahan eksternal yang pesat terjadi di era globalisasi seperti saat ini. Salah satu dari faktor penting tersebut yang harus terpenuhi adalah sebuah manajemen sumber daya manusia (SDM) yang baik.

Sumber daya manusia atau dalam hal ini karyawan adalah aset yang sangat berharga untuk perusahaan. Karyawan merupakan salah satu faktor internal yang sangat berperan menghasilkan barang dan jasa yang berkualitas. Agar hal itu dapat terjadi salah satu cara terbaik yang dapat dilakukan perusahaan adalah dengan membenahi sumber daya manusianya. Manajemen SDM yang baik akan berdampak ke peningkatan kinerja karyawan dan akan berpengaruh langsung dalam peningkatan kinerja perusahaan secara keseluruhan.

Untuk mencapai kinerja karyawan yang unggul, perusahaan perlu mengerti dan memahami apa yang menjadi motivasi dan kebutuhan para karyawan dalam lingkungan kerjanya. Salah satu konsep 
untuk mengembangkan sebuah lingkungan kerja yang baik untuk karyawan adalah konsep kualitas kehidupan kerja atau dikenal juga dengan nama Quality of Work Life (QWL). Konsep ini mengemukakan pentingnya penghargaan terhadap manusia dalam lingkungan kerjanya.

PT. Asabri (Persero) merupakan suatu Badan Usaha Milik Negara (BUMN) yang ditugaskan oleh pemerintah untuk mengelola Program Asuransi Sosial bagi TNI, Polri dan Pegawai Negeri Sipil (PNS) dilingkungan Dephan dan Polri yang sifat kepesertaannya bersifat wajib (compulsory), selalu berupaya meningkatkan pelayanan terhadap peserta dengan memelihara kepercayaan peserta melalui hubungan yang baik dan senantiasa meningkatkan kepuasan peserta melalui peningkatan kualitas pelayanan dan nilai manfaat, memberikan informasi kepada peserta yang berkaitan dengan pelayanan perusahaan secara adil, cepat, lengkap dan akurat serta menghargai dan memberikan apresiasi yang tulus kepada peserta.

Peningkatan layanan dapat tercapai dengan baik manakala pegawai memiliki kinerja yang baik dan selalu senantiasa membina hubungan baik dan harmonis dengan konsumen dengan saling menciptakan hubungan kerja yang harmonis antara perusahaan dengan mitra kerjanya. Seperti halnya PT. Asabri (Persero) Kantor Cabang pembantu Bandar Lampung memberikan penghargaan yang layak kepada mitra kerja peserta Asabri dengan memberikan Reward kepada peserta Asabri agar terciptanya kepuasaan bagi para nasabah PT. Asabri KCP Bandar Lampung.

Selain dipengaruhi oleh kualitas jasa atau pelayanan, kepuasan pelanggan juga ditentukan oleh kinerja individu karyawan. Penilaian kinerja karyawan juga tidak kalah pentingnya, penilaian kinerja karyawan adalah proses penilaian hasil kerja yang akan digunakan oleh pihak manajemen untuk memberikan informasi kepada para karyawan secara individual, tentang mutu hasil pekerjaannya dipandang dari sudut kepentingan perusahaaan. Penilaian yang dilakukan secara teratur bertujuan melindugi perusahaan dalam mencapai tujuannya. Penilaian kinerja karyawan yang dilakukan secara obyektif, tepat, dan didokumentasikan secara baik cenderung menurunkan potensi penyimpangan yang dilakukan karyawan, sehingga kinerjanya 3 diharapkan harus bertambah baik sesuai dengan kinerja yang dibutuhkan perusahaan.

Pengembangan sumber daya manusia perlu dilakukan secara terencana dan berkesinambungan. Agar pengembangan dapat dilaksanakan dengan baik, harus lebih dahulu ditetapkan suatu program pengembangan sumber daya manusia. Progam pengembangan sumber daya manusia hendaknya disusun secara cermat dan didasarkan kepada metode-metode ilmiah serta berpedoman pada keterampilan yang dibutuhkan perusahaan saat ini maupun masa depan. Pengembangan haruslah bertujuan untuk meningkatkan kemampuan teknis, teoritis, konseptual serta moral sumber daya manusia supaya prestasi kerjanya baik dan mencapai hasil yang optimal.

Berdasarkan hal tersebut peneliti tertarik untuk meneliti fenomena tersebut dengan judul: "Pengaruh Pemberian Reward terhadap Peningkatan Kepuasaan Pelanggan pada PT. Asabri (Persero) Kantor Cabang Pembantu Lampung di Bandar Lampung".

\section{KAJIAN TEORI}

\section{Pengertian Reward}

Usaha untuk mendapatkan pegawai yang profesional sesuai dengan tuntutan jabatan diperlukan suatu pembinaan yang berkesinambungan, yaitu suatu usaha kegiatan perencanaan, pengorganisasian, 
penggunaan, dan pemeliharaan pegawai agar mampu melaksanakan tugas dengan efektif dan efisien. Sebagai langkah nyata dalam hasil pembinaan maka dirasa perlu dengan adanya pemberian reward atau penghargaan kepada pegawai yang telah menunjukkan prestasi kerja yang baik. Pemberian reward tersebut merupakan upaya pemimpin dalam memberikan balas jasa atas hasil kerja pegawai, sehingga dapat mendorong bekerja lebih giat dan berpotensi.

Martin dan Pear berpendapat bahwa kata "positive reinforcement" sering disamaartikan dengan kata "hadiah" (reward) (Edi Purwanta, 2005). Muhamad Fahrozin, dkk (2004) mendefinisikan positive reinforcement yaitu stimulus yang pemberiannya terhadap operan behavior menyebabkan perilaku tersebut akan semakin diperkuat atau dipersering kemunculannya. Sejalan dengan pendapat di atas, Dalyono (2009) mengartikan positive reinforcement sebagai penyajian stimulus yang meningkatkan probabilitas suatu respon.

Sedangkan Made Pidarta (2007) mendefinisikan positive reinforcement ialah setiap stimulus yang dapat memantapkan respon pada pengkondisian instrumental dan setiap hadiah yang dapat memantapkan respon pada pengkondisian perilaku. Soetarlinah Sukadji (Edi Purwanta, 2005) menyatakan apabila suatu stimulus berupa benda atau kejadian itu dihadirkan (yang terjadi sebagai akibat atau konsekuensi suatu perilaku) secara berulang-ulang, sehingga keseringan munculnya perilaku tersebut meningkat atau terpelihara, maka peristiwa itu disebut positive reinforcement.

Setiap organisasi menggunakan berbagai reward atau imbalan untuk menarik dan mempertahankan orang dan memotivasi mereka agar mencapai tuiuan pribadi mereka dan tujuan organisasi. Misalnya saja dengan cara memberikan kepada pegawai berupa sertifikat penghargaan, alih tugas, promosi, pujian dan pengakuan dan juga membantu menciptakan iklim yang menghasilkan pekerjaan yang lebih banyak tantangannya dan memuaskan. Sebaliknya, para pegawai menukarkannya dengan waktu, kemampuan, keahlian, dan usaha untuk mendapatkan imbalan yang sesuai. Maksud dari reward yang terpenting bukanlah dari hasil yang dicapai. Melainkan dari hasil yang dicapai tersebut, pemimpin bertujuan untuk membentuk kemauan yang lebih baik dan lebih keras pada pegawainya.

\section{Tujuan Reward}

Menurut Gibson (2002) tujuan pemberian reward yang utama adalah:

a) Menarik (Attract)

Reward harus mampu menarik orang yang berkualitas untuk menjadi anggota organisasi.

b) Mempertahankan (Retain)

Reward juga bertujuan untuk mempertahankan pegawai dari incaran organisasi lain. Sistem reward yang baik dan menarik mampu meminimalkan jumlah pegawai yang keluar.

c) Memotivasi (Motivate)

Sistem reward yang baik harus mampu meningkatkan motivasi pegawai untuk mencapai prestasi yang tinggi.

Menurut Sondang P. Siagian (2002) usaha untuk memenuhi tujuan-tujuan reward tersebut, perlu diikuti tahapantahapan dalam pemberian reward, yaitu:

a. Melakukan analisis pekerjaan, artinya perlu disusun deskripsi jabatan, uraian pekerjaan dan standar pekerjaan yang ditetapkan dalam suatu organisasi.

b. Melakukan penilaian pekerjaan, dalam melakukan penilaian pekerjaan diusahakan tersusunnya urutan peringkat 
pekerjaan, penentuan nilai untuk setiap pekerjaan, susunan perbandingan dengan pekerjaan lain dalam organisasi dan pemberian point untuk setiap pekerjaan.

c. Melakukan survei berbagai sistem penghargaan yang berlaku untuk menentukan keadilan eksternal yang didasarkan pada sistem penghargaan di tempat lain.

d. Menentukan harga setiap pekerjaan untuk menentukan penghargaan yang akan diberikan. Dalam mengambil langkah ini dilakukan perbandingan antara nilai berbagai pekerjaan dalam organisasi dengan nilai yang berlaku di tempat lain pada umumnya.

\section{Pengertian Kepuasaan Pelanggan}

Kepuasan pelanggan merupakan salah satu kunci keberhasilan usaha. Hal ini dikarenakan dengan memuaskan pelanggan, perusahaan dapat meningkatkan tingkat keuntungannya. Dalam hal ini yang akan dibahas adalah perusahaan jasa. Konsumen dalam menggunakan jasa tertentu akan menghasilkan tingkat kepuasan tertentu. Dari service performance (tampilan pelayanan), maka perceived service (pelayanan yang diberikan) tidak mungkin selalu sama dengan customer expectation (harapan konsumen).

Kepuasan konsumen merupakan evaluasi atau penilaian kognitif menyangkut apakah kinerja produk/jasa relatif bagus atau tidak. Masalah kepuasan adalah merupakan masalah perseorangan yang sifatnya subjektif, karena kepuasan sesorang belum tentu sama dengan kepuasan yang dirasakan orang lain. Walaupun jasa yang diberikan mempunyai ciri atau kualitas pelayanan yang sama. Karena itu kepuasan ini sangat sulit diukur secara kuantitatif. Menurut Philip Kotler (2009) kepuasan konsumen adalah hasil yang dirasakan oleh pembeli yang mengalami kinerja sebuah perusahaan dalam bentuk barang atau jasa yang sesuai dengan harapannya. Konsumen merasa puas jika harapan mereka terpenuhi, dan merasa amat sangat senang jika harapan mereka terlampaui

Sedangkan menurut Fandy Tjiptono (2002) menyatakan bahwa, "Kepuasan atau ketidakpuasan pelanggan adalah respon pelanggan terhadap evaluasi ketidaksesuaian/diskonfirmasi yang dirasakan antara harapan sebelumnya (atau norma kinerja lainnya) dan kinerja aktual produk yang dirasakan setelah pemakaiannya

Sedangkan menurut Tjiptono (2000) mengungkapkan bahwa kepuasan pelanggan merupakan evaluasi purna beli dimana alternatif yang dipilih sekurangkurangnya memberikan hasil (outcome) yang sama atau melampaui harapan pelanggan, sedangkan ketidakpuasan timbul apabila hasil yang diperoleh tidak memenuhi harapan pelanggan. Pendapat lain menyatakan bahwa kepuasan pelanggan adalah perasaan seseorang yang puas atau sebaliknya setelah membandingkan antara kenyataan dan harapan yang diterima dari sebuah produk atau jasa (Kotler 2000).

Jadi kualitas pelayanan merupakan hal penting yang harus diperhatikan oleh perusahaan agar dapat tercapai kepuasan konsumen. Kualitas pelayanan memiliki hubungan yang erat dengan kepuasan konsumen. Kualitas memberikan suatu dorongan kepada konsumen untuk menjalin hubungan yang kuat dengan perusahaan. Dalam jangka panjang ikatan ini memungkinkan perusahaan untuk memahami dengan seksama harapan konsumen serta kebutuhannya. Dengan demikian perusahaan dapat meningkatkan kepuasan konsumen dan pada gilirannya kepuasan tersebut dapat menciptakan kesetiaan / loyalitas konsumen. 


\section{Manfaat Kepuasan Pelanggan}

Adapun manfaat-manfaat yang dapat diraih ketika pelanggan merasa puas adalah sebagai berikut menurut Hardiyansyah, (2011) yaitu:

a) Hubungan antar perusahaan dan para pelanggannya menjadi harmonis.

b) Memberikan dasar yang baik bagi pembelian ulang.

c) Dapat mendorong terciptanya loyalitas pelanggan.

d) Membentuk suatu rekomendasi dari mulut ke mulut yang menguntungkan bagi perusahaaan.

e) Reputasi perusahaan menjadi baik di mata pelanggan.

f) Sebagai indikator kesuksesan bisnis.

Sementara faktor-faktor yang mempengaruhi kepuasan pelanggan menurut Lupyoadi (2001) adalah :

a) Kualitas produk, yaitu pelanggan akan merasa puas bila mereka menunjukan bahwa produk yang mereka gunakan berkualitas.

b) Kualitas pelayanan atau jasa, yaitu pelanggan akan merasa puas bila mereka mendapatkan pelayanan yang baik atau yang sesuai dengan yang diharapkan.

c) Emosi, yaitu pelanggan akan merasa bangga dan mendapatkan keyakinan bahwa orang lain akan kagum bila menggunakan produk dengan merek tertentu yang cenderung mempunyai tingkat kepuasan yang lebih baik.

d) Harga, yaitu produk yang mempunyai kualitas yang sama tetapi menetapkan harga yang relatif murah akan memberikan nilai yang lebih tinggi kepada pelanggan.

e) Biaya, yaitu pelanggan yang tidak perlu mengeluarkan biaya tambahan atau tidak perlu membuang waktu untuk mendapatkan suatu produk atau jasa cenderung puas terhadap produk atau jasa tersebut.
Menurut Irawan (2004), faktor-faktor pendorong kepuasan pelanggan adalah sebagai berikut :

a) Kualitas produk, pelanggan puas setelah membeli dan menggunakan produk tersebut ternyata kualitas produknya baik.

b) Harga, untuk pelanggan yang sensitif biasanya harga murah adalah sumber kepuasan yang penting karena pelanggan akan mendapatkan value for money yang tinggi.

c) Service quality, kepuasan terhadap kualitas pelayanan biasanya sulit ditiru. Kualitas pelayanan neruapakan driver yang mempunyai banyak dimensi.

d) Emotional factor, pelanggan akan merasa puas (bangga) karena adanya emotional value yang diberikan oleh brand dari produk tersebut.

e) Biaya dan kemudahan, pelanggan akan semakin puas apabila relatif mudah, nyaman, dan efisien dalam mendapatkan produk atau pelayanan.

\section{METODE PENELITIAN}

\section{Objek Penelitian}

Objek penelitian ini adalah pegawai dan nasabah PT. Asabri (Persero) Jl. Z.A. Pagar Alam No.32 D Gedung Meneng Bandar Lampung yang dilaksanakan selama 2 bulan dari bulan Juni sampai dengan bulan Agustus 2016.

\section{Metode dan Teknik Pengumpulan Data}

Metode yang digunakan dalam menganalisis data penelitian ini mengenai hubungan antara variabel bebas X ( Pemberian Reward) dengan variabel terikat Y (Kepuasaan Pelanggan). Menurut pendapat Singarimbun (2009) analisis kulitatif, yaitu menganaliis data berdasarkan pendekatan teoritis dan literatur manajemen personalia dan 
manajemen sumber daya manusia, berupa keterangan dan penjelasan. Sedangkan analisis kualitatif adalah menganalisis data penelitian dengan menggunakan perhitungan statistik.

Dalam penelitian ini jenis data yang diperlakukan adalah :

a. Data Primer

Data primer merupakan data dasar yang akan diperoleh langsung tanpa perantara orang atau lembaga lain sebagai pihak ketiga. Data primer ini diperoleh dengan wawancara melalui responden dengan menggunakan daftar pertanyaan.

\section{b. Data Sekunder}

Data skunder merupakan data yang diperoleh melalui orang lain yang berhubungan dengan permasalahan yang dipecahkan. Data sekunder ini diperoleh melalui cara studi dokumenter yaitu mengumpulkan dan mempelajari brosurbrosur serta dokumen organisasi.

\section{Sampel dan Populasi}

Purposive sampling berarti teknik pengambilan sempel secara sengaja. Maksudnya , peneliti menentukan sendiri sampel yang diambil tidak secara acak, tapi ditentukan sendiri oleh peneliti. Pengambilan sampel berdasarkan "penilaian" peneliti mengenai siapa-siapa saja yang pantas memenuhi persyaratan untuk dijadikan sampel.

Oleh karena itu latar belakang pengetahuan tertentu mengenai sampel dimaksud tentu juga populasinya agar benar-benar bisa mendapatkan sampel yang sesuai dengan persyaratan atau tujuan peneliti yang sehingga mendapat atau memperoleh data yang akurat. Berdasarkan hal tersebut, maka penulis menentukan sampel sebanyak 25 orang responden yang diambil secara acak berdasarkan penilaian penulis.

\section{Metode Analisis Data}

\section{Analisis Kualitatif}

Analisis kualitatif bertujuan untuk menganalisis pokok permasalahan berdasarkan konsep manajemen personalia dan manajemen sumber daya manusia mengenai teori-teori tentang pegawai dan nasabah PT. Asabri (Persero) Jl. Z.A. Pagar Alam No.32 D Gedung Meneng Bandar Lampung.

\section{Analisis Kuantitatif}

Analisis kualitatif adalah bertujuan untuk menganalisis data primer penelitian diperoleh berdasarkan hasil penyebaran instrumen pertanyaan kepada Peserta PT Asabri (Persero) Kantor Cabang Lampung di Bandar Lampung mengenai (Pemberian Reward X) dengan (Kepuasaan Pelanggan sebagai Variabel Y).

Dalam upaya menjawab permasalahan dalam penelitian ini maka digunakan analisis regresi linier sederhana, analisis regresi pada dasarnya adalah studi mengenai ketergantungan variabel dependen (terikat) dengan satu atau lebih variabel independen (bebas), dengan tujuan untuk mengestimasi dan memprediksi ratarata populasi atau nilai-nilai variabel dependen berdasarkan nilai variabel independen yang diketahu (Ghozali, 2006).

Persamaan regresi dalam penelitian ini adalah untuk mengetahui seberapa besar pengaruh variabel independen atau bebas yaitu Pemberian Reward (X) terhadap variabel dependen yaitu Kepuasaan Pelanggan (Y). Rumus persamaan regresi linier sederhana yang digunakan dalam penelitian ini adalah:

$$
Y=a+b X+e
$$

Keterangan:

$$
\mathrm{Y}=\text { Kepuasan pelanggan }
$$


$\mathrm{a}=$ Konstanta

$\mathrm{b}=$ Koefisien regresi $\mathrm{X}$

$\mathrm{X}=$ Pemberian reward

$\mathrm{e}=$ Faktor kesalahan

Untuk menguji secara hipotesis secara parsial digunakan Uji t dengan rumus :

$$
t_{\text {hitung }}=\frac{r \sqrt{N-2}}{\sqrt{1-r^{2}}}
$$

Keterangan:

$$
\begin{array}{ll}
\mathrm{t}_{\text {hitung }} & =\text { Nilai } \mathrm{t} \\
\mathrm{r} & =\text { Koefisien Korelasi } \\
\mathrm{N} & =\text { Jumlah responden }
\end{array}
$$
berikut :

Kriteria untuk Uji $\mathrm{t}$ adalah sebagai

a) Jika $t_{\text {hitung }}>t_{\text {tabel }}$ maka Ha diterima dan Ho ditolak.

b) Jika $t_{\text {hitung }} \leq \mathrm{t}_{\text {tabel }}$ maka Ha ditolak dan Ho diterima.

\section{HASIL DAN PEMBAHASAN}

\section{Analisis Kualitatif}

Berdasarkan rekapitulasi data hasil dari 25 responden tentang pengaruh pemberian reward terhadap Peningkatan Kepuasaan Pelanggan PT. Asabri (Persero) KCP Lampung adalah sebagai berikut 8 responden $(32 \%)$ mendapat kategori sangat baik,10 responden (40\%) responden mendapat kategori baik, 7 responden $(28 \%)$ responden kategori cukup dan yang mendapat kategori kurang dan buruk tidak ada selanjutnya untuk mengetahui kepusaan pelanggan PT. Asabri (Persero) Kantor Cabang Lampung 8 responden (32\%) memiliki mendapat kategori sangat baik, 14 responden $(56 \%)$ mendapat kategori baik dan 3 responden (12\%) mendapat kategori cukup. Hasil tersebut menunjukan bahwa pengaruh pemberian reward terhadap peningkatan kepuasaan pelanggan PT.
Asabri (Persero) Kantor Cabang Lampung berpengaruh signifikan.

\section{Analisis Kuantitatif}

Setelah dilakukan uji validitas Pemberian reward (X) diketahui bahwa 20 butir item pertanyaan di atas dapat dinyatakan 20 butir item valid karena mimiliki nilai corrected item-total correlation $>0.396$. Sedangkan variabel Kepuasaan Pelanggan (Y) item pernyataan sebanyak 20 butir dari ke-20 penyataan tersebut dinyatakan instramen valid semua karena mimiliki nilai corrected item-total correlation $>0.396$.

Berdasarkan uji reliabilitas kuisioner menunjukkan bahwa Cronbach Alpha untuk variabel pemberian reward SDM birokrasi memiliki nilai $0.840>0.60$ dan untuk variabel kepuasaan pelanggan memiliki nilai $0.746>0.60$, berdasarkan hasil tersebut maka semua instrument variabel dalam penelitian ini adalah reliabel (konsisten) ini dikarenenakan nilai Cronbach Alpha $>0.60$.

Berdasarkan uji descriptive statistics menunjukkan bahwa skor pemberian reward diperoleh skor minimum 65 maksimum 95 rata-rata 84,36 std deviation 7.931 dan varian 62.907 sedangkan untuk Kepuasaan Pelanggan sebesar minimum 62, maksimum 94 rata -rata 78.80 std deviatin 10,890 dan varian 118.583 Berdasarkan nilai rata-rata skor di atas maka diketahui bahwa pemberian reward dan kepuasaan pelanggan memiliki nilai interval yang tidak jauh sehingga dapat diasumsikan bahwa indikator yang penulis tawarkan kepada responden sesuai dengan fakta empiris pada Pelanggan atau Peserta PT. Asabri (Persero) Bandar Lampung.

Uji determinasi menjelaskan besarnya keseragaman pemberian reward yang dipengaruhi oleh satu variabel bebasnya, pada hasil di atas dikoefisien determinasi ( $R$ Square) sebesar 0.751 atau secara 
statistik $75.1 \%$ pemberian reward dipengaruhi oleh kepuasaan pelanggan. Sedangkan sisanya $(100 \%-75.1 \%)=$ $24.9 \%$ pemberian reward dipengaruhi oleh faktor-faktor lain selain variabel bebas yang sedang penulis teliti.

Berdasarkan perhitungan diperoleh koefisien regresi sebesar 34.610 dan konstanta sebesar 0.631, maka dapat digambarkan bentuk pengaruh variabel pemberian reward terhadap kepuasaan pelanggan dalam bentuk persamaan regersi $\mathrm{Y}=34.610+0.631 \mathrm{X}$ ini berarti bahwa jika pemberian reward meningkat sebesar 1 poin maka kepuasaan pelanggan akan meningkat sebesar 0.631 poin pada konstanta 34.610. Sehingga dengan kata lain bahwa semakin baik pemberian reward maka kepuasaan pelanggan akan semakin tinggi sehingga berdampak kepada kepercayaan pelanggan terhadap PT. Asasbri (Persero) cabang lampung didalam memberikan kepercayaan kepada pelanggan.

Berdasarkan Uji $\mathrm{t}$ thitung untuk Pemberian reward sebesar 34,610 sedangkan $t_{\text {tabel }}$ sebesar dengan dk (25-2 = 23) adalah 1.699, jadi $t_{\text {hitung }} 34,610>t_{\text {tabel }}$ $0.05(\mathrm{dk} 23)=1.713$, sehingga dengan demikian $\mathrm{Ho} 2$ ditolak $\mathrm{Ha} 2$ diterima dapat disimpulkan bahwa memang terdapat pengaruh yang signifikan antara pemberian reward terhadap kepuasaan pelanggan Pada PT. Asabri (Persero) Cabang Lampung.

\section{KESIMPULAN DAN SARAN}

\section{Kesimpulan}

Berdasarkan hasil penelitian dan pembahasan maka dapat disimpulkan bahwa koefisien regresi sebesar 34,610 dan konstanta sebesar 0.631, maka dapat digambarkan bentuk pengaruh variabel pemberian reward terhadap kepuasaan pelanggan dalam bentuk persamaan regersi $\mathrm{Y}=34,610+0,631 \mathrm{X}$ ini berarti bahwa jika pemberian reward meningkat sebesar 1 poin maka kepuasaan pelanggan akan meningkat sebesar 0,631 poin pada konstanta 34,610. Sehingga dengan kata lain bahwa semakin baik pemberian reward maka kepuasaan pelanggan akan semakin tinggi sehingga berdampak kepada kepercayaan pelanggan terhadap PT. Asasbri (Persero) cabang Lampung.

\section{Saran}

Adapun saran yang dapat diberikan dari penelitian ini adalah sebagai berikut :

1. Hendaknya karyawan PT Asabri (persero) Cabang Lampung selalu memberikan reward kepada peserta PT Asabri (Persero) secara kontinyu agar peserta PT Asabri (persero) mendapat kepuasaan tersendiri dari PT Asabri (Persero).

2. Hendaknya pegawai PT Asasbri ( Persero) Cabang Lampung memberikan trobosan-trobosan seperti pemberian reward kepada para peserta PT Asabri (Persero) Cabang Lampung.

\section{DAFTAR PUSTAKA}

Davis, K dan Newstrom. 2003. Perilaku dalam Organisasi. Jakarta: Erlangga.

Fathoni. 2006. Organisasi Dan Manajemen Sumber Daya Manusia. Jakarta: Rineka Cipta.

Gozali, Imam. 2005. Aplikasi Analisis Multivariat dengan SPSS. Semarang: Penerbit Universitas Diponegoro.

Handoko, T Hani. 2004. Manajemen Sumber Daya Manusia. Yogyakarta: BPFE.

Hasibuan, Malayu S.P. 2005. Manajemen Sumber Daya Manusia. Jakarta: Bumi Aksara. 
Kreitner, Robert and Angelo Kinicki. 2001.

Organizational Behavior. Hill: Irwin McGraw.

Mangkunegara, Anwar Prabu. 2007. Evaluasi Kinerja Sumber Daya Manusia. Bandung: PT. Refika Aditama.

Manullang. 2001. Manajemen Sumber Daya Manusia Pada Perusahaan. Jakarta: Erlangga.

Mathis, Robert. L dan Jackson, Jhon H. 2006. Manajemen Sumber Daya manusia, Penerjemah Jimmi sadeli dan Bayu prawira Hie. Jakarta: Penerbit Salemba Empat.

Mobley. 2002. Manajemen Sumber Daya Manusia dan Perusahaan. Jakarta: Salemba Empat.

Robbins, Stephen P. 2003. Perilaku Organisasi: Konsep, Kontroversi, Aplikasi, Alih Bahasa Hadyana Pujaatmaka dan Benyamin Molan, Jilid Pertama. Jakarta: Prenhallindo.

Sastrohadiwiryo, Siswanto. 2002. Manajemen Tenaga Kerja Indonesia Pendekatan Administrasi dan Operasional. Jakarta: Bumi Aksara.

Saydam, Gouzali. (2006). Manajemen Sumber Daya Manusia. Jakarta: PT. Toko Gunung Agung.

Soeprihanto, John. 2001. Penilaian Kinerja dan Pengembangan Karyawan. Yogyakarta: Universitas Gadjah Mada.

Tambunan. 2012. Prioritas Pencapaian Kinerja Karyawan. Yogyakarta: Universitas Gajah Mada. 